\title{
Management of the grape mealy bug, Maconellicoccus hirsutus (Green), using entomopathogenic fungi and botanical oils: a laboratory study
}

\author{
Gurav Shrishail Gopal', Balaiah Venkateshalu², A. M. Nadaf², P. N. Guru ${ }^{3 *}$ and Sateesh Pattepur ${ }^{4}$
}

\begin{abstract}
Background: Laboratory experiments were conducted to evaluate the bio-efficacy and cumulative effect of entomopathogenic fungi (EPF), viz., Lecanicillium lecanii (Zimmermann) Zare and Gams, and Beauveria bassiana (Balsamo) Vuillemin and different botanical oils against grape mealy bug, Maconellicoccus hirsutus (Green). M. hirsutus infestation during berry formation has left no option other than chemical management. However, the pesticide application during this stage leads to residues. Thus, safer and sustainable biological need was tested for their effectiveness against $M$. hirsutus.

Results: Dipping bioassay technique was used to determine the cumulative mortality. When L. lecanii was used as sole (at 6 and $4 \mathrm{~g} /$ ), significant mortality was observed (51.63 and 50.18\%). However, the maximum cumulative nymphal mortality was achieved when the combination of EPF formulations was used, i.e., $57.64 \%$ with B. bassiana + L. lecanii $(6 \mathrm{~g} / \mathrm{l}+6 \mathrm{~g} / \mathrm{l})$. Their effectiveness was at par with the same combination but with minimal concentration, i.e., $4 \mathrm{~g} / \mathrm{l}+4 \mathrm{~g} / \mathrm{l}$ (56.29\%). Concerning the botanical oils evaluated, neem oil at $15 \mathrm{ml} / \mathrm{l}$ achieved a higher mortality of $81.36 \%$. Consecutive effective treatment was a combination of neem oil and pongamia oil (at $10+10 \mathrm{~m} / \mathrm{l})$ with $79.65 \%$ mortality. However, the standard dosage of neem oil (at $10 \mathrm{ml} / \mathrm{l})$ and IIHR neem soap (at $10 \mathrm{~g} / \mathrm{l})$ also recorded the significant mortality of 78.09 and $77.67 \%$, respectively. When compared, the neem oil was found significantly superior in sole and compatible combination than pongamia oil.
\end{abstract}

Conclusions: Lecanicillium lecanii and neem oil (sole and in combination with other compatible bioagents) proved significantly better for the management against M. hirsutus with an efficacy of 90.21 and $96.67 \%$ mortality, respectively against the standard chemical control (more than 97\%).

Keywords: Maconellicoccus hirsutus, Entomopathogenic fungi, Lecanicillium, Beauveria, Botanicals, Neem oil, IIHR neem soap

\section{Background}

India is one of the top ten countries in the world in the production of grapes. The area under grape cultivation is $1.2 \%$ of the total area of fruit crops in the country. Production is $2.8 \%$ of total fruits produced in the

\footnotetext{
*Correspondence: gurupn5016@gmail.com; guru.pn@icar.gov.in ${ }^{3}$ ICAR-Central Institute of Post-Harvest Engineering and Technology, Ludhiana, Punjab 141004, India

Full list of author information is available at the end of the article
}

country (Anonymous 2018). In wet and warm climates like India, grapevine cultivation is being challenged by several biotic factors like insect pests and diseases. As many as 100 insect and mite pests have been reported to infest and cause damage to grapevine in India. Among 26 insect pests recorded, grape mealy bug, Maconellicoccus hirsutus (Green) (Hemiptera: Pseudococcidae), was recorded as a major, dreaded, and regular pest of grapes. In recent years, the infestation of grape mealy bug, $M$. 
hirsutus, has become very severe, making the fruits unfit for consumption and raisin making.

Hot and dry climatic conditions are highly favorable for sucking insects like $M$. hirsutus. It is present throughout the year but found to be active from June to August and again from November to March. Infestation starts from pruning to the harvest of fruit bunches and was difficult to manage thus also referred to as "hard to kill pest of fruit trees." Grape mealy bug alone reported to cause around $50-100 \%$ yield loss in field conditions (Manjunath 1985) because of direct and indirect damage. They cause indirect damage by excreting honeydew leading to sooty mold encrustation, loss of photosynthetic ability, and ultimately impairing the quality and quantity of yield.

The management of grape mealy bug is very complicated because of several factors like lack of in-time mealy bug detection and availability of proper monitoring tools and cryptic behavior of the insect. The protective waxy covering over the body of the mealy bug prevents the insecticides from gaining entry into the body of the insect (Geiger et al. 2001). The present mealy bug management strategies in grapevine rely solely upon the use of insecticides. The over-dependence on pesticides, particularly during the fruiting stages of crop results in residues in the harvestable produce apart from numerous other drawbacks like pollution, toxicity to non-target animals and plants, and insecticide resistance (Aktar et al. 2009). There is an overwhelming need to develop non-chemical, ecofriendly, and sustainable management strategies against mealy bug.

Botanical oils are widely used in insect management because of their repellent property, antifeedant nature, growth-inhibiting activity, easy biodegradability, and safety to non-target insects (Oparaeke et al. 2005). Similarly, entomopathogenic fungi (EPF) are relatively broader in the mode of entry (both contact and systemic) and target group compared to other biological options. Integration of selected strains of EPF with selective botanical or insecticides can improve the control efficiency, besides decrease, the amount of insecticides required, minimize the risks of environmental contamination, and can delay the expression of insecticide resistance in insect pests. However, the botanical oils and EPF, when used alone were proven less effective under field conditions leading to low adaptability.

Therefore, the present experimentation objective was to evaluate the enhanced efficacy of the combination of EPF, viz., Beauveria bassiana and Lecanicillium lecanii, and botanical oils, viz., neem oil and pongamia oil against $M$. hirsutus under laboratory conditions.

\section{Methods}

Test insect (Maconellicoccus hirsutus) culture

Ripened red pumpkins of medium size with ridges and grooves with a small stalk were used. Minor wounds on the pumpkins were plugged with paraffin wax. To prevent rotting, the pumpkins were treated with $0.1 \%$ carbendazim 50 WP at $1 \mathrm{~g} / \mathrm{l}$ of water for $10 \mathrm{~s}$ and shade dried for $4 \mathrm{~h}$. A simple roping technique has been adopted with 2-4 mm cotton thread tied over the pumpkin both vertically and horizontally (Babu and David 1999). The egg sacs of mealy bugs were collected from grape orchards and released on pumpkins. The inoculated pumpkins were kept in wooden cages $(30 \times 30 \times$ $33 \mathrm{~cm}$ ) with sliding glass in the front and mesh cage on all other sides for population buildup (Katake and Balikai 2008). Fully matured mealy bugs developed within 30 to 40 days. The subsequent culture was maintained by periodic transfers of mealy bugs to fresh pumpkins under laboratory conditions.

\section{Preparation of entomopathogenic fungi (EPF) solutions} Local strains of EPF, viz., B. bassiana (WP with $2 \times 10^{8}$ $\mathrm{cfu} / \mathrm{g}$ ) and L. lecanii (WP with $2 \times 10^{8} \mathrm{cfu} / \mathrm{g}$ ), and their combinations were used as treatments (Table 1). The cultures of EPF, viz., B. bassiana and L. lecanii, were obtained from biocontrol laboratory, UHS, Bagalkote, India. The formulations of $80 \% \mathrm{WP}$ containing $2 \times 10^{8}$ $\mathrm{cfu} / \mathrm{g}$ were utilized for the treatment. The formulated products were kept under normal room temperature and $\mathrm{RH}\left(30-35{ }^{\circ} \mathrm{C}\right.$ and $90-95 \%$, respectively). The silicon-based agricultural adjuvant (Sure shot ${ }^{\circ}$ ) was obtained from local market, used a wax dissolving agent.

\section{Preparation of botanical oil solution}

In total, 16 treatments were carried out, comprising neem oil, pongamia oil, fish oil rosin soap (FORS), and their combinations along with azadirachtin, IIHR neem soap, standard checks, and untreated control. Treatments were replicated thrice and laid out in CRD. Treatment solution of five liters was prepared in a plastic container distilled with water along with the wetting agent, Sure $\operatorname{shot}^{\circ}(0.25 \mathrm{ml} / \mathrm{l})$ for tuber dip treatment. The locally available neem and pongamia oils were obtained (extracted from plants) from the market and are used as such along with adjuvant (Sure shot). The adjuvant acts as a surfactant, and it dissolves the wax coating. It helps in uniform spread of oils and their easy dissolve in the water.

\section{Culturing on potato tubers}

Good quality, medium-sized potato tubers with robin eyes were placed in plastic trays $(45 \times 30 \times 10 \mathrm{~cm})$ filled 3/4th with sterilized river sand. Carbendazim (Bavistin $^{\circ}$ ) was added at $5 \mathrm{~g} / \mathrm{kg}$ of sterilized sand and 
Table 1 Treatment details for the efficacy of entomopathogenic fungi against Maconellicoccus hirsutus

\begin{tabular}{lllll}
\hline Tr. no. & Treatments & Colony units/gram & Formulation & Concentration (g or ml/l of water) \\
\hline 1 & Lecanicillium lecanii & $2 \times 10^{8} \mathrm{cfu} / \mathrm{g}$ & WP & 2 \\
2 & L. lecanii & $2 \times 10^{8} \mathrm{cfu} / \mathrm{g}$ & WP & 4 \\
3 & L. leanii & $2 \times 10^{8} \mathrm{cfu} / \mathrm{g}$ & WP & 6 \\
4 & Beauveria bassiana & $2 \times 10^{8} \mathrm{cfu} / \mathrm{g}$ & WP & 2 \\
5 & B. bassiana & $2 \times 10^{8} \mathrm{cfu} / \mathrm{g}$ & WP & 4 \\
6 & B. bassiana & $2 \times 10^{8} \mathrm{cfu} / \mathrm{g}$ & WP & 6 \\
7 & L. lecanii + B. bassiana & $2 \times 10^{8} \mathrm{cfu} / \mathrm{g}$ & WP & $2+2$ \\
8 & L. lecanii + B. bassiana & $2 \times 10^{8} \mathrm{cfu} / \mathrm{g}$ & WP & $4+4$ \\
9 & L. lecanii + B. bassiana & $2 \times 10^{8} \mathrm{cfu} / \mathrm{g}$ & WP & $6+6$ \\
10 & Imidacloprid 17.8 SL (Confider $\left.{ }^{\oplus}\right)$ & - & - & 0.25 \\
11 & Wetting agent (Sure shot ${ }^{\oplus}$ ) & - & - & 0.25 \\
12 & Distilled water (sole) & - & - & - \\
13 & Untreated control (no spray) & - & - & - \\
\hline
\end{tabular}

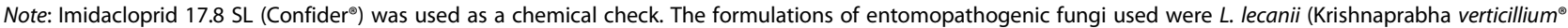
$80 \mathrm{WP})$ and B. bassiana (Krishnaprabha Beauveria $₫ 0$ WP)

mixed well to avoid fungal infection to the tubers and to avoid rotting of potato sprouts. These trays were kept in a separate darkroom to facilitate quick sprouting. After 7 days tubers containing 4-5 sprouts were removed carefully to avoid damage. The potato sprouts were inoculated with mealy bug crawlers (30-35 crawlers/sprout), using a hair brush. The inoculated sprouts were kept in the rearing room for their establishment. After 5 days, only around 20 numbers of 2nd instar crawlers were retained on sprouts.

\section{Tuber dip bioassay}

The established potato sprouts with 20 numbers of 2 nd instar crawlers were dipped in treatment solution (5 lit) for $30 \mathrm{~s}$ and shade dried. The treated sprouts were then rearranged in sand-filled trays at equidistance and maintained at $25 \pm 5^{\circ} \mathrm{C}$ and $75 \pm 5 \mathrm{RH}$ (Mohamed 2016). Three replications with 8 such mealy bug colonized sprouts per each replication were dipped in a chemical solution, thus $\sim 480$ mealy bugs per treatment were tested.

\section{Observations}

The mortality of nymphs was recorded at $3,5,7,9,11$, and 15 days after tuber dip bioassay treatment. The immobilized crawlers were recorded as dead and further confirmed by observing under the microscope for spores. Cadavers of dead mealy bugs were kept in a humid chamber for 2 days or inoculated on to Petri plates containing PDA to observe the hyphal growth, for further confirmation.

\section{Statistical analysis}

The number of mealy bugs found dead per mealy bugs released or recorded initially (pre-treatment count of 20) on the sprouts was used to calculate mortality. The percent mortality of mealy bugs was worked out by using Abbott's formula for each treatment in all replications. Before statistical analysis, data on corrected percent mortality was subjected to arcsine transformation and performed one-way ANOVA by adopting the "Fisher's analysis of variance technique." The means were compared at 5\% CD using Duncan's multiple range test (DMRT) (Gomez and Gomez, 1984).

No. in $\mathrm{T}$ after treatment

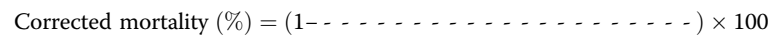

No. in Co after treatment

where $\mathrm{n}$ is the number of insect or population, $\mathrm{T}$ is treated, and Co is control

\section{Results}

The experimental results by dipping bioassay indicated the superiority of all the treatments over water spray (UTC) throughout the experimental period. Nymphs infected with the EPF were turned relatively hard and mummified. After $24 \mathrm{~h}$ of the death of the nymphs, germination of the conidia and penetration of hyphae through the integuments of nymphs were observed. Later, the entire body surface was covered with mycelial growth.

\section{Efficacy of entomopathogenic fungi}

The data regarding the average cumulative mortality of nymphs of mealy bug caused by different treatments 
after dipping bioassay experiments were found statistically significant at every interval of observations, i.e., 3, 5, 7, 9, 11, and 15 DAT (Table 2). The data indicated that combinations of fungal pathogens $(B$. bassiana and L. lecanii) at different doses recorded significantly higher per cent mortality of nymphs than the sole treatments. Combination of B. bassiana at $6 \mathrm{~g} / \mathrm{l}+L$. lecanii at $6 \mathrm{~g} / \mathrm{l}$ recorded the highest mortality of $90.21 \%$ at 15 days after treatment and was at par with $B$. bassiana at $4 \mathrm{~g} / 1+L$. lecanii at 4 $\mathrm{g} / \mathrm{l}(88.96 \%)$. The next promising treatments in recording moderate percent mortality of nymphs were L. lecanii at 6 and $4 \mathrm{~g} / \mathrm{l}(82.30$ and $83.96 \%$ at 15 DAT, respectively).

Considering the overall performance of the different treatments, the significantly highest mean mortality of mealy bug nymphs was registered in chemical check, imidacloprid $17.8 \mathrm{SL}$ at $0.25 \mathrm{ml} / 1$ (87.61\%). Among the fungal bioagents, combinations of B. bassiana $(6 \mathrm{~g})+$ L. lecanii $(6 \mathrm{~g})$ recorded numerically the highest mean nymphal mortality (57.64\%), and it was statistically at par with its next concentration, B. bassiana $(4 \mathrm{~g})+$ L. lecanii $(4 \mathrm{~g})$ (56.29\%) and were significantly superior over rest of treatments and found most effective in causing mortality of mealy bugs. Among the sole treatments $L$. lecanii at $6 \mathrm{~g} / \mathrm{l}$ (51.63\%), followed by L. lecanii at 4 $\mathrm{g} / \mathrm{l}(50.18 \%)$ found best. On the contrary, B. bassiana treatments recorded relatively lower percent mortality of mealy bugs than $L$. lecanii. The treatment, $B$. bassiana at $6 \mathrm{~g}$, recorded only $30.97 \%$ mortality almost equal to B. bassiana at $4 \mathrm{~g}(30.56 \%)$.

\section{Efficacy of botanical oils against $M$. hirsutus}

The experimental results by dipping bioassay indicated the superiority of all the treatments over water spray (UTC) throughout the experimental period (Table 3). Among the botanicals, neem oil at $15 \mathrm{ml} / \mathrm{l}$ recorded significantly highest \% mortality of mealy bugs $(60.00$, 71.46 , and $78.13 \%$ at 3,5 , and 7 DAT, respectively) and was statistically at par with neem oil at $10 \mathrm{ml} / \mathrm{l}(76.88 \%)$ at $7 \mathrm{DAT}$ and were significantly superior over, pongamia oil at $15 \mathrm{ml} / \mathrm{l}(32.71 \%)$ and fish oil rosin soap at $15 \mathrm{ml} / \mathrm{l}$ (63.55\%). However, the chemical check imidacloprid $17.8 \mathrm{SL}$ at $0.25 \mathrm{ml} / \mathrm{l}$ was obviously superior to other treatments by recording mortality of $91.88 \%$.

Among the botanicals, maximum mean nymphal mortality was noticed in neem oil at $15 \mathrm{ml}(81.36 \%)$. The next best order of effectiveness was neem oil $(10 \mathrm{ml})+$ pongamia oil $(10 \mathrm{ml})(79.65 \%)$, neem oil at $10 \mathrm{ml}$ (78.09\%), and IIHR neem soap at $10 \mathrm{~g}$ (77.67\%). However, FORS at $10 \mathrm{ml}$ recorded moderate mortality of $63.38 \%$ and was statistically on par with its high concentration at $15 \mathrm{ml}(60.74 \%)$. The treatments, pongamia oil at $15 \mathrm{ml}$ and $10 \mathrm{ml}$, were found very less effective and recorded moderate mealy bug mortality with 36.63 and $35.11 \%$, respectively. The mean mealy bug mortality registered in chemical check, imidacloprid 17.8 SL at 0.25 $\mathrm{ml}$ was significantly the highest $(89.69 \%)$.

\section{Discussion}

The fungal pathogens act primarily by cuticular degradation, followed by the development of fungal hyphae and spores on the insect body. The cuticular degradation may be due to the secretion of hydrolytic enzymes such

Table 2 Efficacy of entomopathogenic fungi against Maconellicoccus hirsutus under laboratory condition

\begin{tabular}{|c|c|c|c|c|c|c|c|}
\hline \multirow[t]{2}{*}{ Treatment } & \multirow[t]{2}{*}{ Treatment details } & \multicolumn{6}{|c|}{ Cumulative mortality of nymphs (\%) } \\
\hline & & 3DAT & 5DAT & 7DAT & 9DAT & 11DAT & 15DAT \\
\hline $\mathrm{T1}$ & Lecanicillium lecanii at $2 \mathrm{~g} / \mathrm{l}$ & $10.00^{\mathrm{e}}(18.42)$ & $16.46^{\mathrm{e}}(23.90)$ & $32.09^{\mathrm{e}}(34.48)$ & $46.88^{\mathrm{e}}(43.19)$ & $57.92^{d}(49.54)$ & $67.08^{\mathrm{e}}(54.97)$ \\
\hline $\mathrm{T} 2$ & L. lecanii at $4 \mathrm{~g} / \mathrm{l}$ & $12.92^{\mathrm{d}}(21.05)$ & $27.09^{\complement}(31.33)$ & $45.00^{\mathrm{C}}(42.11)$ & $58.13^{\mathrm{d}}(49.66)$ & $73.96^{\mathrm{C}}(59.30)$ & $83.96^{C}(66.38)$ \\
\hline T3 & L. lecanii at $6 \mathrm{~g} / \mathrm{l}$ & $17.50^{c}(24.71)$ & $28.75^{\complement}(32.41)$ & $47.08^{\mathrm{C}}(43.31)$ & $63.34^{\complement}(52.72)$ & $70.84^{c}(57.31)$ & $82.30^{c}(65.11)$ \\
\hline T4 & Beauveria bassiana at $2 \mathrm{~g} / \mathrm{l}$ & $4.79^{9}(12.57)$ & $13.13^{f}(21.17)$ & $17.50^{9}(24.69)$ & $32.09^{9}(34.48)$ & $35.63^{f}(36.62)$ & $42.71^{9}(40.79)$ \\
\hline T5 & B. bassiana at $4 \mathrm{~g} / \mathrm{l}$ & $5.84^{9}(13.96)$ & $12.92^{f}(21.01)$ & $25.42^{f}(30.25)$ & $37.09^{f}(37.50)$ & $46.67^{\mathrm{e}}(43.07)$ & $55.42^{f}(48.09)$ \\
\hline T6 & B. bassiana at $6 \mathrm{~g} / \mathrm{l}$ & $7.92^{f}(16.33)$ & $13.54^{\mathrm{ef}}(21.54)$ & $27.29^{f}(31.47)$ & $35.84^{f}(36.75)$ & $44.59^{\mathrm{e}}(41.87)$ & $56.67^{f}(48.81)$ \\
\hline $\mathrm{T7}$ & B. bassiana + L. lecanii at $2 \mathrm{~g} / \mathrm{l}$ each & $11.88^{\mathrm{de}}(20.13)$ & $20.21^{d}(26.66)$ & $40.00^{d}(39.21)$ & $54.79^{d}(47.73)$ & $60.00^{d}(50.75)$ & $75.63^{d}(60.42)$ \\
\hline T8 & B. bassiana + L. lecanii at $4 \mathrm{~g} / \mathrm{l}$ each & $18.96^{\mathrm{bc}}(25.76)$ & $33.75^{\mathrm{b}}(35.49)$ & $48.13^{\mathrm{c}}(43.91)$ & $68.75^{\mathrm{b}}(55.99)$ & $79.17^{\mathrm{b}}(62.86)$ & $88.96^{\mathrm{b}}(70.64)$ \\
\hline T9 & B. bassiana + L. lecanii at $6 \mathrm{~g} / \mathrm{l}$ each & $20.42^{\mathrm{b}}(26.84)$ & $35.00^{\mathrm{b}}(36.25)$ & $52.71^{\mathrm{b}}(46.53)$ & $66.25^{\mathrm{bc}}(54.46)$ & $81.25^{\mathrm{b}}(64.33)$ & $90.21^{b}(71.77)$ \\
\hline $\mathrm{T} 10$ & Imidacloprid $17.8 \mathrm{SL}$ at $0.25 \mathrm{ml} / \mathrm{I}$ & $70.42^{\mathrm{a}}(57.04)$ & $81.67^{\mathrm{a}}(64.64)$ & $89.17^{\mathrm{a}}(70.79)$ & $92.08^{\mathrm{a}}(73.70)$ & $95.21^{\mathrm{a}}(77.37)$ & $97.08^{\mathrm{a}}(80.49)$ \\
\hline $\mathrm{T} 11$ & Wetting agent + water at $0.25 \mathrm{ml} / /$ & $1.04^{\mathrm{h}}(5.79)$ & $1.46^{9}(6.90)$ & $1.67^{h}(7.39)$ & $2.09^{h}(8.28)$ & $2.92^{9}(9.82)$ & $3.54^{h}(10.83)$ \\
\hline $\mathrm{T} 12$ & Water alone & $0.00^{i}(0.00)$ & $1.04^{9}(5.79)$ & $1.25^{\mathrm{h}}(6.42)$ & $1.25^{\mathrm{h}}(6.42)$ & $1.46^{\mathrm{h}}(6.90)$ & $1.67^{i}(7.39)$ \\
\hline $\mathrm{T} 13$ & Untreated control & $0.00^{i}(0.00)$ & $0.00^{\mathrm{h}}(0.00)$ & $0.00^{i}(0.00)$ & $0.00^{i}(0.00)$ & $0.00^{i}(0.00)$ & $0.00^{j}(0.00)$ \\
\hline
\end{tabular}

Note: Twenty mealybug nymphs per sprout were released and considered as pre-treatment count $(20 \times 8 \times 3=480$ mealybugs per treatment). Figures in the parentheses are arcsine transformed values; the mean values with the same alphabetical superscripts are statistically non-significant as per DMRT DAT days after treatment 
Table 3 Efficacy of botanical oils against Maconellicoccus hirsutus under laboratory condition

\begin{tabular}{|c|c|c|c|c|c|c|c|}
\hline \multirow[t]{2}{*}{ Treatment } & \multirow[t]{2}{*}{ Treatment details } & \multicolumn{6}{|c|}{ Mortality of nymphs (\%) } \\
\hline & & 3DAT & 5DAT & 7DAT & 9DAT & 11DAT & 15DAT \\
\hline $\mathrm{T1}$ & Azadirachtin $10,000 \mathrm{ppm}$ at $1 \mathrm{ml} / \mathrm{l}$ & $44.79^{\mathrm{e}}(41.99)$ & $54.38^{\mathrm{e}}(47.49)$ & $\begin{array}{l}73.96^{\mathrm{cd}} \\
(59.32)\end{array}$ & $\begin{array}{l}76.04^{c} \\
(60.68)\end{array}$ & $\begin{array}{l}79.17^{d} \\
(62.86)\end{array}$ & $82.92^{f}(65.61)$ \\
\hline $\mathrm{T} 2$ & Neem oil at $10 \mathrm{ml} / \mathrm{l}$ & $\begin{array}{l}56.46^{\mathrm{bcd}} \\
(48.69)\end{array}$ & $\begin{array}{l}67.92^{\mathrm{bc}} \\
(55.49)\end{array}$ & $\begin{array}{l}76.88^{\mathrm{bc}} \\
(61.31)\end{array}$ & $\begin{array}{l}85.00^{\mathrm{b}} \\
(67.31)\end{array}$ & $\begin{array}{l}92.92^{\mathrm{b}} \\
(74.59)\end{array}$ & $\begin{array}{l}94.17^{c d} \\
(76.12)\end{array}$ \\
\hline T3 & Neem oil at $15 \mathrm{ml} / \mathrm{l}$ & $60.00^{\mathrm{b}}(50.76)$ & $71.46^{b}(57.72)$ & $\begin{array}{l}78.13^{\mathrm{bc}} \\
(62.15)\end{array}$ & $\begin{array}{l}87.92^{b} \\
(69.74)\end{array}$ & $\begin{array}{l}93.96^{\mathrm{b}} \\
(75.82)\end{array}$ & $\begin{array}{l}96.67^{b} \\
(79.97)\end{array}$ \\
\hline T4 & IIHR neem soap at $10 \mathrm{~g} / \mathrm{l}$ & $\begin{array}{l}55.00^{c d} \\
(47.85)\end{array}$ & $62.09^{d}(51.98)$ & $80.42^{\mathrm{b}}(63.79)$ & $\begin{array}{l}86.05^{\mathrm{b}} \\
(68.12)\end{array}$ & $\begin{array}{l}90.21^{c} \\
(71.81)\end{array}$ & $\begin{array}{l}92.30^{\text {de }} \\
(73.93)\end{array}$ \\
\hline T5 & Pongamia oil at $10 \mathrm{ml} / \mathrm{l}$ & $15.84^{h}(23.42)$ & $23.55^{\mathrm{h}}(29.00)$ & $31.88^{9}(34.33)$ & $\begin{array}{l}40.42^{f} \\
(39.46)\end{array}$ & $\begin{array}{l}46.88^{9} \\
(43.19)\end{array}$ & $52.09^{i}(46.18)$ \\
\hline T6 & Pongamia oil at $15 \mathrm{ml} / \mathrm{l}$ & $20.63^{9}(26.96)$ & $24.79^{\mathrm{h}}(29.82)$ & $32.71^{9}(34.86)$ & $\begin{array}{l}39.79^{f} \\
(39.09)\end{array}$ & $\begin{array}{l}48.54^{9} \\
(44.15)\end{array}$ & $53.34^{i}(46.89)$ \\
\hline T7 & Neem oil at $5 \mathrm{ml} / \mathrm{l}+$ Pongamia oil at $5 \mathrm{ml} / \mathrm{l}$ & $54.17^{d}(47.37)$ & $\begin{array}{l}66.88^{\mathrm{bcd}} \\
(54.86)\end{array}$ & $70.00^{d}(56.86)$ & $\begin{array}{l}73.34^{c} \\
(58.98)\end{array}$ & $\begin{array}{l}81.67^{d} \\
(64.63)\end{array}$ & $\begin{array}{l}90.84^{\mathrm{e}} \\
(72.39)\end{array}$ \\
\hline T8 & $\begin{array}{l}\text { Neem oil at } 10 \mathrm{ml} / \mathrm{l}+\text { Pongamia oil at } 10 \\
\mathrm{ml} / \mathrm{l}\end{array}$ & $\begin{array}{l}59.17^{\mathrm{bc}} \\
(50.27)\end{array}$ & $\begin{array}{l}69.38^{b c} \\
(56.44)\end{array}$ & $\begin{array}{l}75.83^{\mathrm{bcd}} \\
(60.55)\end{array}$ & $\begin{array}{l}86.25^{b} \\
(68.28)\end{array}$ & $\begin{array}{l}91.88^{b c} \\
(73.46)\end{array}$ & $\begin{array}{l}95.42^{\mathrm{bc}} \\
(77.92)\end{array}$ \\
\hline T9 & FORS at $5 \mathrm{ml} / /$ & $30.00^{f}(33.18)$ & $32.50^{9}(34.74)$ & $39.80^{f}(39.09)$ & $\begin{array}{l}49.17^{\mathrm{e}} \\
(44.51)\end{array}$ & $55.00^{f}(47.85)$ & $\begin{array}{l}59.79^{h} \\
(50.63)\end{array}$ \\
\hline $\mathrm{T} 10$ & FORS at $10 \mathrm{ml} / /$ & $\begin{array}{l}51.67^{c d} \\
(48.09)\end{array}$ & $55.42^{\mathrm{e}}(48.09)$ & $61.25^{\mathrm{e}}(51.49)$ & $\begin{array}{l}64.38^{\mathrm{d}} \\
(53.38)\end{array}$ & $\begin{array}{l}72.09^{e} \\
(58.11)\end{array}$ & $\begin{array}{l}75.42^{9} \\
(60.26)\end{array}$ \\
\hline T11 & FORSat $15 \mathrm{ml} / \mathrm{l}$ & $42.29^{e}(40.55)$ & $42.71^{f}(40.79)$ & $63.55^{\mathrm{e}}(52.84)$ & $\begin{array}{l}67.08^{d} \\
(54.98)\end{array}$ & $\begin{array}{l}71.46^{\mathrm{e}} \\
(57.70)\end{array}$ & $\begin{array}{l}77.30^{9} \\
(61.52)\end{array}$ \\
\hline $\mathrm{T} 12$ & $\begin{array}{l}\text { Neem oil + pongamia oil + FORS at } 5 \mathrm{ml} / \mathrm{l} \\
\text { each }\end{array}$ & $53.13^{d}(46.77)$ & $\begin{array}{l}65.42^{c d} \\
(53.96)\end{array}$ & $\begin{array}{l}72.92^{c d} \\
(58.67)\end{array}$ & $\begin{array}{l}77.71^{\mathrm{c}} \\
(61.83)\end{array}$ & $\begin{array}{l}78.96^{d} \\
(62.70)\end{array}$ & $84.79^{f}(67.03)$ \\
\hline $\mathrm{T} 13$ & Imidacloprid $17.8 \mathrm{SL}$ at $0.25 \mathrm{ml} / \mathrm{I}$ & $71.67^{\mathrm{a}}(57.84)$ & $82.29^{\mathrm{a}}(65.13)$ & $91.88^{\mathrm{a}}(73.46)$ & $\begin{array}{l}95.84^{\mathrm{a}} \\
(78.25)\end{array}$ & $\begin{array}{l}97.29^{\mathrm{a}} \\
(80.71)\end{array}$ & $\begin{array}{l}99.17^{\mathrm{a}} \\
(84.80)\end{array}$ \\
\hline $\mathrm{T} 14$ & Water + wetting agent at $0.25 \mathrm{ml} / \mathrm{l}$ each & $1.25^{\mathrm{i}}(6.42)$ & $1.67^{i}(7.39)$ & $1.88^{\mathrm{h}}(7.87)$ & $2.29^{9}(8.68)$ & $2.92^{\mathrm{h}}(9.82)$ & $3.75^{\mathrm{j}}(11.16)$ \\
\hline $\mathrm{T} 15$ & Water alone & $0.00^{\mathrm{j}}(0.00)$ & $1.04^{i}(5.79)$ & $1.25^{\mathrm{h}}(6.42)$ & $1.25^{9}(6.42)$ & $1.46^{i}(6.90)$ & $1.88^{k}(7.87)$ \\
\hline T16 & Untreated control & $0.00^{\mathrm{j}}(0.00)$ & $0.00^{j}(0.00)$ & $0.00^{i}(0.00)$ & $0.00^{h}(0.00)$ & $0.00^{j}(0.00)$ & $0.00^{1}(0.00)$ \\
\hline
\end{tabular}

Note: Twenty mealybug nymphs per sprout were released and considered as pre-treatment count $(20 \times 8 \times 3=480$ mealybugs per treatment). Figures in the parentheses are arcsine transformed values; the mean values with the same alphabetical superscripts are statistically non-significant as per DMRT

DAT days after treatment, FORS Fish Oil Rosin Soap

as proteases, lipases, and chitinases which play an important role in the infection process (Banu et al. 2010).

Among the sole and combinational treatments of EPF, the combination of $L$. lecanii with $B$. bassiana was found superior over the sole treatments (Fig. 1). When these biopesticides used in sole, L. lecanii was found significantly superior to B. bassiana at the tested doses (4 and $6 \mathrm{~g} / \mathrm{l})$. These bioagents were found effective in reducing the mealy bug population by causing mortality at the range of $42.71 \%$ to more than $90 \%$ at 15 DAT. The maximum mortality in the combination of both $B$. bassiana and $L$. lecanii may be attributed to potentiation but with limited synergetic action of both the entomopathogens. When used in sole, the L. lecanii recorded $83.96 \%$ mortality at the highest concentration and was almost 2 times significant than $B$. bassiana that recorded only $56.67 \%$ mortality at the same concentration. Of the two EPF, L. lecanii showed a high mortality on all stages of mealy bugs, which is in agreement with the results of
Russell and Paterson (2006). The highest efficacy on mealy bugs could be because of production of mycotoxins, viz., helvolic acid, bassianolide, cytochalasin $\mathrm{C}$ and $\mathrm{D}$, destruxins, and faster mycelial growth to penetrate into the body of the host which caused septicemia to the mealy bug, leading to early death as compared to other entomopathogens like Metarhizium anisopliae (Metschinkoff) Sorokin and B. bassiana (Banu et al. 2010).

The treatments with $B$. bassiana recorded lower nymphal mortality (around 20-30\%) on grape mealy bug than to L. lecanii. Similarly, Amala et al. (2014) reported that $B$. bassiana was less effective against grape mealy bug than $L$. lecanii with $\mathrm{LC}_{50}$ and $\mathrm{LT}_{50}$ values of $1.5 \times$ $10^{6}$ and 3.04 days, respectively. Jeyarani et al. (2011) also reported that B. bassiana could cause $50 \%$ mortality of cotton mealy bug, Planococcus solenopsis Tinsley (Hemiptera: Pseudococcidae) at $3.6 \times 10^{7}$ spore $/ \mathrm{ml}$ concentration and is in conformity with present findings, wherein 


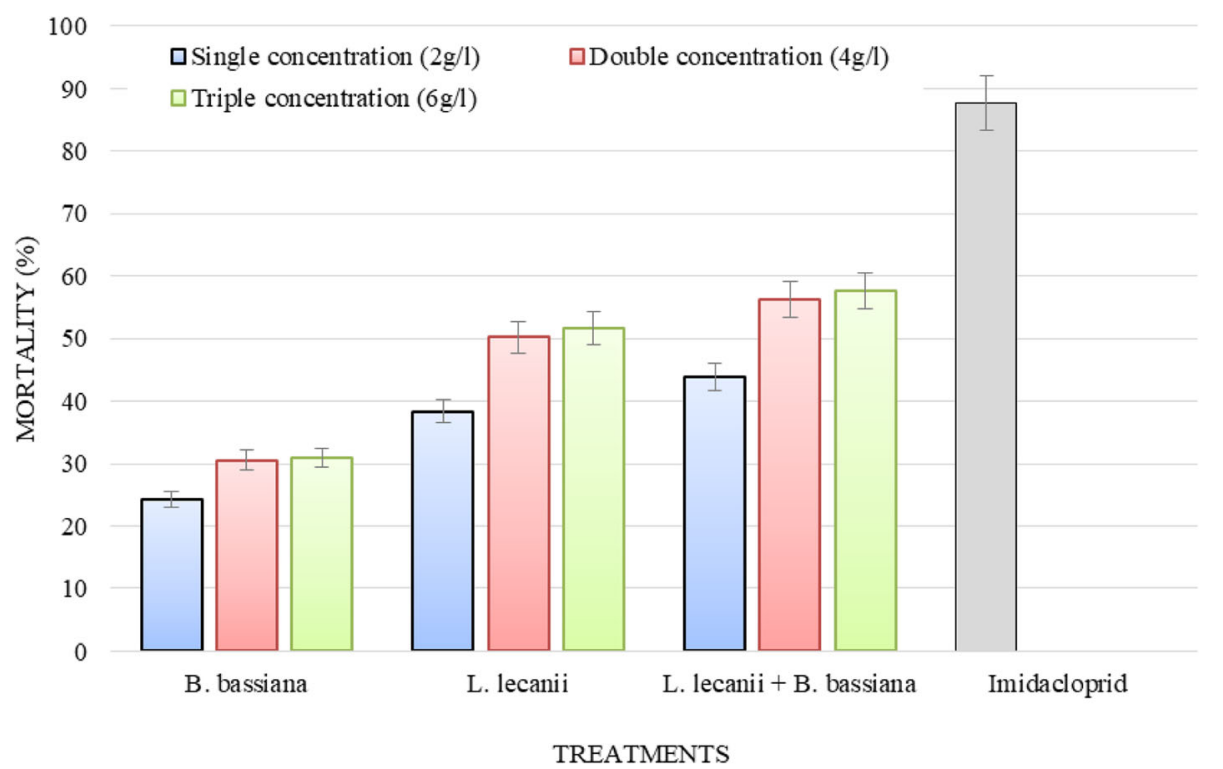

Fig. 1 Comparatice efficacy of Lecanicillium lecanii and Beauveria bassiana against Maconellicoccus hirsutus under laboratory condition

the present trial the spore concentration used was $2 \times$ $10^{8} \mathrm{cfu} / \mathrm{ml}$. Kanitkar et al. (2020) revealed that application of Brigade-BL (B. bassiana) at $5.0 \mathrm{ml} / \mathrm{l}$ with 2 sprayings resulted in reduction of mealy bug colonies up to 67.82 and $75.68 \%$ in foundation and fruiting pruning, respectively. Similarly, it has not resulted in any abnormality and phytotoxic effects like leaf chlorosis, tip burning, necrosis, epinasty, and rusting on grapevines and were found compatible with Buprofezin 25 SC chemical insecticide.

Treatment with insecticide, imidacloprid at $0.25 \mathrm{ml} / \mathrm{l}$ significantly affected the mealy bug population by recording mortality of more than $90 \%$. The systemic nature of imidacloprid in tuber dip bioassay, resulted in effective suppression of mealy bugs whereas, the topical application of contact insecticides many times fail to cause mortality in mealy bugs because of the heavy waxy coatings on the body surface. Reports of Meyerdirk et al. (2004) also suggested some biological characteristics of the pest like secretion of wax, waxy ovisac, and the ability to oviposit on foreign substrates which led to difficulty in control of mealy bugs. Perhaps, this difficulty could be quite evident especially in contact insecticides compared to systemic insecticides.

The use of a wetting agent is very important prerequisite to dissolve waxy secretions in mealy bugs for easy deposition and penetration of fungal bodies. Though wetting agent itself caused negligible mortality of mealy bugs, its addition along with EPF is an essential pre-requisite, as the mode of entry of these EPFs is through the cuticle. In addition to the wetting agents, several other additives have also proved promising in recording increased mortality of mealy bug. A similar kind of effort made by Chavan and Kadam (2010) recorded a maximum of $82.50 \%$ mortality of $M$. hirsutus nymphs in formulations containing $V$. lecanii + glycerol $8 \%+$ Tween 80 at $1 \%$ and Arachid oil $0.5 \%$.

The early stages of mealy bugs are more susceptible to fungal biopesticides in general and $L$. lecanii in specific. In the present investigations, the first and second instar nymphs of $M$. hirsutus were selected and probably are more susceptible to EPF like L. lecanii than the later instars. In addition, EPFs had latent infection periods ranging from 5 to 10 days, which results in the escape of infection in late-stage nymphs. Ten days after EPF treatment, the highest mortality of 65.10 and $58.99 \%$ of the first and second nymphal instars of $M$. hirsutus was recorded, respectively, whereas 45.96 and $30.66 \%$ mortality in third instar nymphs and adult mealy bugs, respectively (Makadia et al. 2009).

In addition to these factors, the time required for infection, moribund, and mortality is important and depends on the stage of the pest. So, the present study was found to be in conformity with the finding of Halder et al. (2013), where the \% mortality of nymphs increased with the increase in time where, 6 days after the spraying, $V$. lecanii (at $2 \times 10^{9} \mathrm{cfu} / \mathrm{g}$ ) caused the mortality of $67.11 \%$, followed by $B$. bassiana $\left(1 \times 10^{8} \mathrm{cfu} / \mathrm{g}\right)$ and $M$. anisopliae $\left(1 \times 10^{8} \mathrm{cfu} / \mathrm{g}\right)$ with 62.85 and $56.52 \%$ mortality, respectively. Among the 3 tested fungal pathogens, L. lecanii at $1 \times 10^{8}$ spores $/ \mathrm{ml}$ was proved to be an efficient entomopathogen with increased efficiency as the infection time prolonged. The mean fecundity of adult females treated with $L$. lecanii was lower (54.20 eggs/female) with a significant reduction in the hatchability of the eggs (25.20). This is reflected clearly in the present 
studies, indicating greater post pathogenicity and speed of kill in L. lecanii ( $63.34 \%$ in 9 days) than B. bassiana (35.84\% in 9 days). Further, the virulence of $L$. lecanii was maintained even in combination with B. bassiana. $L$. lecanii recorded 26.00 to $82.28 \%$ mortality from first to fourth nymphal instars of mealy bug, $M$. hirsutus infesting custard apple (Makadia et al. 2009).

Among the botanical oils/formulations, significantly high cumulative nymphal mortality was noticed in neem oil at $15 \mathrm{ml} / \mathrm{l}(81.36 \%)$ and was statistically on par with neem oil + pongamia oil at $10+10 \mathrm{ml} / \mathrm{l}(79.65 \%)$, neem oil at $10 \mathrm{ml} / \mathrm{l}(78.09 \%)$, and IIHR neem soap at $10 \mathrm{~g} / \mathrm{l}$ (77.67\%). In general, the formulations made of or extracted from neem proved effective in managing the mealy bug population. Neem oil acts in many ways like insect growth regulator, feeding deterrent, and larvicidal activity. So, multiple modes of action of neem-based botanical oils qualify it as a unique insecticidal product and proved superior compared to pongamia oil. At $15 \mathrm{ml} / \mathrm{l}$ dose, neem oil was found significantly superior to all the other botanicals tested.

Verghese (1997) reported 5 and 2.5\% neem seed kernel extracts as highly effective in causing mortality of early instar $M$. hirsutus nymphs after 24 and $48 \mathrm{~h}$, after treatment under laboratory condition, while commercial product, Econeem ${ }^{\circ}$ (Azadirachtin) $1500 \mathrm{ppm}$ was effective on late instar mealy bugs after 24 and $48 \mathrm{~h}$. of treatment. On the contrary, Banu et al. (2010) reported a moderate mortality in nymphs and adults (42.22 and $55.56 \%$, respectively) of cotton mealy bug, $P$. solenopsis with NSKE at $5 \%$, while neem oil + Nirma ${ }^{\circ}$ powder caused 46.67 and $57.78 \%$ mortality of nymphs and adults, respectively, after $48 \mathrm{~h}$ of treatment. This might be due to thick waxy coating and high body mass of late instar nymphs and adults. However, early instar nymphs were more susceptible to neem oil at high concentrations $(15 \mathrm{ml} / \mathrm{l})$ or in combination with pongamia oil at $10+10 \mathrm{ml} / \mathrm{l}$. The results are in close agreement with Kumar et al. (1989) on the coffee green scale, Coccus viridis (Green) (Hemiptera: Coccidae), and Manjunath et al. (1992) on mealy bug, M. hirsutus.

More than $70 \%$ mortality was exhibited by commercial neem products are supported by Shekhar and Sathyaprasad (1998) who reported appreciable mortality of nymphs (95 to $98 \%$ ) with Rakshak ${ }^{\circ}$ and Amruthaguard ${ }^{\circ}$ $(0.5 \%)$, while their efficacy reduced on adults (around $51 \%)$ of $M$. hirsutus under laboratory conditions.

The time taken for causing more than 50\% mortality of second or third instars was shortest ( 3 days) in case of neem oil at $15 \mathrm{ml} / \mathrm{l}(60.00 \%$ mortality), indicating quicker penetration and action. The results are corroborated with findings of Halder et al. (2013) who reported $\mathrm{LT}_{50}$ for neem oil $5 \%$ as $93.71 \mathrm{~h}$, while it is blending with a fungal pathogen like L. lecanii, B. bassiana, and $M$. anisopliae at 1:1 ratio exhibited $\mathrm{LT}_{50}$ of $87.67,88.34$, and $90.82 \mathrm{~h}$, respectively. So, in the present findings, the superiority of neem oil as a sole treatment is quite evident compared to its blends.

The treatments with pongamia oil at $15 \mathrm{ml} / \mathrm{l}$ and 10 $\mathrm{ml} / \mathrm{l}$ were recorded moderate nymphal mortality of 36.63 and $35.11 \%$, respectively. On the contrary, Verghese and Tandon (1987) reported that pongamia oil (2\%) was very effective in killing crawlers of $M$. hirsutus, which could be because of high concentrations compared to present studies.

Fish oil rosin soap (FORS) at $10 \mathrm{ml} / \mathrm{l}$ recorded moderate nymphal mortality (63.38\%) and was on par with FORS at $15 \mathrm{ml} / \mathrm{l}(60.74 \%)$, followed by FORS at $5 \mathrm{ml} / \mathrm{l}$ (44.37\%). All the combinations of treatments with FORS gave moderate to high mortality and it could be due to enhancement of botanical penetration into insect body by dissolving the waxy filament layer. Overall, FORS concentrations performed inferior than neem oil at similar concentrations.

\section{Conclusions}

In the present study, the virulence of $L$. lecanii alone and their combinations was higher than that of B. bassi$a n a$ and among all the different botanicals, neem oil had a different mode of action resulted in causing significantly high mortality of nymphs. The laboratory results of the present study against mealy bug with different EPF and botanicals are useful for further experimental studies under field conditions. Due to the waxy coating on the body, the insecticidal management of mealy bug in the field is quite difficult and in addition, it can create several environmental issues, so encouraging the biopesticide and botanicals oils can be recommended.

\section{Abbreviations}

NSKE: Neem seed kernel extract; $L_{C_{50}}$ : Lethal concentration 50\%; $L T_{50}$ : Lethal time 50\%; SL: Soluble liquid; DAT: Days after treatment; UTC: Untreated control; DMRT: Duncan's multiple range test; ANOVA: Analysis of variance; PDA: Potato dextrose agar; CRD: Completely randomized design; FORS: Fish Oil Rosin Soap; cfu/g: Colony-forming units per gram; WP: Wettable powder; IIHR: Indian Institute of Horticultural Research; EPF: Entomopathogenic fungi; DBT: Days before treatment

\section{Acknowledgements}

The authors are thankful to the Department of Entomology, University of Horticultural Sciences, Bagalkot, and the entire faculty for providing necessary facilities for conducting the investigation and valuable suggestions during the course of the investigation.

\section{Authors' contributions}

All authors have read and approved, prepared, and submitted the final manuscript.

GSG: experimentation, recording observations, and analysis of the data $\mathrm{BV}$ : formulation of the research and guiding the proper work plan and experimentation

NAM: experimentation and analysis of the data

GPN: paper writing and analysis and interpretation of the data

SP: raw material availability, lab culture maintenance, and recording of the observations 


\section{Funding}

Not applicable

\section{Availability of data and materials}

Not applicable

\section{Declarations}

\section{Ethics approval and consent to participate}

The research paper is written based on the novel work done under laboratory conditions. The authors have understood and formulated the paper in response to research ethics.

\section{Consent for publication}

Not applicable

\section{Competing interests}

The authors declare that they have no competing interests.

\section{Author details}

${ }^{1}$ ICAR-Central Institute of Post-Harvest Engineering and Technology, Ludhiana, Punjab 141004, India. ${ }^{2}$ Department of Entomology, College of Horticulture, University of Horticultural Sciences, Bagalkote, Bagalkote, Karnataka 587104, India. ${ }^{3}$ ICAR-Central Institute of Post-Harvest Engineering and Technology, Ludhiana, Punjab 141004, India. ${ }^{4}$ Department of Fruit Science, College of Horticulture, University of Horticultural Sciences, Bagalkote, Bagalkote, Karnataka 587104, India.

Received: 24 March 2021 Accepted: 19 June 2021

Published online: 02 July 2021

\section{References}

Aktar W, Sengupta D, Chowdhury A (2009) Impact of pesticides use in agriculture: their benefits and hazards. Interdiscip Toxicol 2(1):1-12. https:// doi.org/10.2478/v10102-009-0001-7

Amala U, Chinniah C, Sawant IS, Muthukrishnan N, Muthiah C (2014) Bio-efficacy and lethal reproductive effects of three entomopathogenic fungi and botanicals against pink mealy bug, Maconellicoccus hirsutus (Green) infesting grapes. Green Farming 5(4):697-700

Anonymous (2018) Horticulture statistics at a glance 2018. Indian Horticulture Database, National Horticultural Board. Department of Agriculture, Cooperation and Farmers' Welfare, Horticulture Statistics Division

Babu BG, David PMM (1999) A simple technique for mealy bug multiplication on grooveless pumpkins. J Biol Control 13(1-2):59-63

Banu JG, Surulivelu T, Amutha M, Gopalakrishnan N (2010) Laboratory evaluation of insecticides and biopesticides against Phenococcus solenopsis and Paracoccus marginatus infesting cotton. J Biopesticides 3(1):343-346

Chavan BP, Kadam JR (2010) Effect of liquid formulations of Pochonia (Verticillium) lecanii (Zimm.) Viegas on viability and virulence against mealy bug. Annals PI Prot Sci 18(1):63-66

Geiger CA, Daane KM, Bently WJ, Yokota GY, Martin LA (2001) Sampling programme for grape mealy bugs improves pest management. Calif Agric 55(3):19-27. https://doi.org/10.3733/ca.v055n03p19

Gomez KA, Gomez AA (1984) Statistical Procedures for Agricultural Research. Wiley, New York, p 680

Halder J, Rai AB, Kodandaram MH (2013) Compatibility of neem oil and different entomopathogens for the management of major vegetables sucking pests. Nat Acad Sci Lett 36(1):19-25. https://doi.org/10.1007/s40009-012-0091-1

Jeyarani S, Banu JG, Ramaraju K (2011) First record of natural occurrence of Cladosporium cladosporoides (Fresenius) and Beauveria bassiana (Bals-Criv) Vuill on cotton mealy bugs from India. J Entomol 6(3):274-279

Kanitkar S, Raut VM, Sawant SD, Yadav DS, Kulkarni M, Kadam M (2020) Field bioefficacy of "Brigade-BL" (Beauveria bassiana) an Entomopathogenic fungi for the management of mealy bugs on Thompson Seedless Grapes. Int J Res Appl Sci Biotechnol 7(5):306-314. https://doi.org/10.31033/ijrasb.7.5.40

Katake MK, Balikai RA (2008) Comparative biology of grape mealy bug, Maconellicoccus hirsutus on sprouted potato during winter and summer. Indian J Entomol 70(4):395-397

Kumar MG, Bhat PK, Vijayalakshmi GK (1989) Screening of kerosene and neem extract against coffee green scale. J Coffee Res 19(1):51-55
Makadia RR, Kabaria BB, Jethva DM, Virani VR (2009) Bio-efficacy and cumulative effect of Verticillium lecanii against Maconellicoccus hirsutus on custard apple. Agric Sci Dig 29(4):300-302

Manjunath D, Kishore R, Satyaprasad K, Vinod K, Pradip K, Datta RK (1992) Biology of mulberry mealy bug and predatory potential of its biocontrol agent. In: Annual Report (1992-93). Central Sericultural Research and Training Institute (CSRTI), Mysore, pp 50-51

Manjunath TM (1985) Maconellicoccus hirsutus on grapevine. FAO PI Prot Bull 33(2):74

Meyerdirk DE, Muniappan R, Warkentin R, Bamba J, Reddy GVP (2004) Biological control of the papaya mealy bug, Paracoccus marginatus (Hemiptera: Pseudococcidae) in Guam. PI Prot Quart 19:110-114

Mohamed GS (2016) Virulence of entomopathogenic fungi against the vine mealy bug, Planococcus ficus (Signoret) (Hemiptera: Pseudococcidae). Egyptian J Biol Pest Control 26(1):47-51

Oparaeke AM, Dike MC, Amatobi Cl (2005) Evaluation of botanical mixtures for insect pests management on cowpea plants. J Agric Rural Dev Trop Subtrop 106(1):41-48

Russell R, Paterson M (2006) Fungi and fungal toxins as weapons. Mycol Res 110: 1003-1010

Shekhar MA, Sathyaprasad K (1998) Control of mealy bug using neem based insecticides. In: Annual Report. CSRTI, Mysore, p 42

Verghese A (1997) Colony number, size and reproductive potential of the grape mealy bug, Maconellicoccus hirsutus (Green) on laboratory host pumpkin Insect Environ 2(4):139-140

Verghese A, Tandon PL (1987) Pest management in grapevine and guava. In: Annual Report. Indian Institute of Horticultural Research, Bangalore, p 61

\section{Publisher's Note}

Springer Nature remains neutral with regard to jurisdictional claims in published maps and institutional affiliations.

\section{Submit your manuscript to a SpringerOpen ${ }^{\circ}$ journal and benefit from:}

- Convenient online submission

- Rigorous peer review

- Open access: articles freely available online

- High visibility within the field

- Retaining the copyright to your article

Submit your next manuscript at $\boldsymbol{\nabla}$ springeropen.com 